\title{
Seroepidemiology of Bluetongue Virus Infection in Northeast and Southeast Anatolia, Turkey"
}

\author{
Taner KARAOĞLU ${ }^{1}$, İrfan ÖZGÜNLÜK ${ }^{2}$, Yakup YILDIRIM ${ }^{3}$, Elvin GÜNGÖR ${ }^{1}$, \\ Çiğdem OĞUZOĞLU ${ }^{1}$, Seval Bilge DAĞALP', Aykut ÖZKUL ${ }^{1}$, Feray ALKAN ${ }^{1}$, Yılmaz AKÇA ${ }^{1}$, \\ İbrahim BURGU ${ }^{1}$
}

\footnotetext{
${ }^{1}$ Department of Virology, Faculty of Veterinary Medicine, Ankara University, Ankara. ${ }^{2}$ Department of Virology, Faculty of Veterinary Medicine, Kafkas University, Kars. ${ }^{3}$ Department of Virology, Faculty of Veterinary Medicine, Harran University, Şanliurfa, Turkey.
}

\begin{abstract}
Summary: Bluetongue virus infection is an arboviral disease, which infects domestic and wild ruminants. It is characterized by oedema and hemorrhages, especially in reproductive system of both female and male animals. It causes economic losses associated with decrease in fertility problems, abortions and congenital malformation. Bluetongue virus a member of orbivirus genus within the family Reoviridae has 24 serotypes. There is no cross-neutralization between 24 serotypes and that is the biggest problem for prevention and control. For the success of the prophylactic immunization, serotype-spesific vaccine should be used. This research's first step is to determine the seroprevalance in northeast and southeast Anatolian regions in Turkey by selecting two local governmental herds per region. After selection regional herd candidates, one "sentinel herd" in each region was established by selecting seronegative individuals. These herds sampled every month during one year and monitored for bluetongue specific antibody using competitive ELISA. Seroconverted individuals' blood samples tested by antigen capture ELISA and the process of the virus isolation were started. There was no seroconversion in the sentinel herd selected from northeast Anatolia while the seroconversion was detected in the sentinel herd from southeastern Anatolia in Turkey. Blood samples of seroconverted cattle were tested by antigen-capture ELISA in order to detect possible bluetongue viruses. Viral antigen was not detectable at the end of antigen-capture ELISA. Serum samples of seroconverted animals in different periods were re-tested using virus neutralizing assay for detection of individual $\mathrm{SN}_{50}$ values. It was found that BTV type 9 was circulating in the herd from southeastern Anatolia during the sampling period.
\end{abstract}

Key words: Bluetongue, seroepidemiology, serotype, Turkey.

\section{Türkiye’nin Kuzeydoğu ve Güneydoğu Anadolu Bölgelerinde Mavidil Virus Enfeksiyonunun Seropidemiyolojisi}

Özet: Mavidil virus enfeksiyonu, sokucu sineklerle nakledilen, evcil ve bazı yabani ruminantlarda konjesyon, ödem ve hemorajiler ile karakterize, döl veriminde azalma, abort ve konjenital malformasyonlar nedeniyle önemli ekonomik kayıplara neden olan bir enfeksiyondur. Mavi dil enfeksiyonunda bilinen 24 serotipi arasında düşük düzeyde çapraz nötralizasyonun olması, enfeksiyondan korunma ve mücadelede en büyük engeli oluşturmakta, enfeksiyonun çıktığı mihraklarda koruyucu aşılamadan başarılı sonuç alınabilmesi için enfeksiyonu oluşturan serotipe spesifik aşının uygulanmasını gerekli kılmaktadır. Söz konusu araştırma ile kuzeydoğu ve güneydoğu Anadolu bölgelerinde yerleşik birer kamu işletmesinde Mavidil seronegatif bireylerden oluşan 'Nöbetçi sürü'ler oluşturuldu. Bu sürüler bir yıl boyunca birer aylık periyotlar ile örneklendi. Kuzeydoğu Anadolu bölgesinde oluşturulan nöbetçi sürüde hiçbir hayvanda serokonversiyon gözlenmezken güneydoğu Anadolu bölgesinde oluşturulan nöbetçi sürüde serokonversiyon tespit edildi. Serokonverte olan hayvanların kan örnekleri antijen capture ELISA testine tabi tutularak virus varlığı araştırıldı. Antijen capture ELISA testi sonucunda viral antijen saptanamadı. Söz konusu işletmede serokonversiyon gösteren hayvanların farklı dönemlerdeki kan örneklerine BT-4, BT-9 ve BT-16 için yapılan $\mathrm{SN}_{50}$ testi sonuçlarına göre, örnekleme zamanında işletmede BT-9 sirkülasyonun varlığı tespit edildi. Elde edilen bulgular ilgili işletmelerin genel müdürlüğü ile paylaşıldı.

Anahtar sözcükler: Mavidil, seroepidemiyoloji, serotip, Türkiye.

\section{Introduction}

Bluetongue is an important disease of ruminants and is caused by an arthropod-borne Orbivirus, Reoviridae. Climate, vectors and presence of reservoir animals play important roles in the epidemiology of bluetongue (BT) infection. The most important reservoir is cattle, which rarely show symptoms except in case of occurrences by serotype $8(3,5)$. The biggest obstacle for

\footnotetext{
* This research was supported by Scientific Research Projects Coordination Unit of Ankara University, Project Nr: 2006-08-10-078.
} 
controlling the disease is that the virus has 24 serotypes $(3,5,16)$, with low cross reactivity between these serotypes.

The high seroprevalence is caused by various factors, both geographical and climatic: long distance transport of the virus via wind-blown biting flies increases the probability of different serotypes arriving from neighboring countries; there is also inadequate information about the serotype or serotypes causing bluetongue infection. This makes it important to carry out a study of BT in this area. Following the completion of the Atatürk Dam, the southeast region has developed irrigated farming, which has caused significant changes to the ecological balance of the region. The most striking change concerns the survival rates and/or variety of the population of biting flies that act as vectors of various pathogens. The same is also partially valid for the northeast Anatolian region. The serious lack of awareness in neighboring countries about viral infections causing economic losses, such as BT, is also an issue.

The main aim of this study was to establish a warning system to enable the early detection of BT virus serotype invasions in northeast and southeast Anatolia through the deployment of 'sentinel herds' formed of seronegative individuals. To achieve this aim, routine monthly serological and virological surveys of two sentinel herds in each region were planned for one year to allow the serotypic identification of the virus in seroconversion detected cattle.

In order to contribute to the economic success of Turkey's livestock breeding sector, the most important objective of this study, once it had identified the serotypes causing infection in both regions, was to inform the relevant institutions in order for them to produce serotype specific vaccines to carry out an efficient vaccination to prevent further BT infection.

\section{Materials and Methods}

The sampled animals: The animals used for establishment of sentinel herds were selected by random sampling and testing process in four state-owned herds (Herd I, II, III, and IV) from northeast and southeast Anatolian regions. A total of 1440 serum samples were collected from mentioned cattle herds for initial BT testing. The location of herds and number of serum samples withdrawn were given in table 1. Based on serological monitoring data, two sentinel herds with animals aged between 6 to 18 months were constituted: one from 114 seronegative cattle from the herd II in the northeast Anatolian region; and one from 101 seronegative cattle from the herd III in the southeast Anatolian region.

Competitive ELISA test: The competitive ELISA test was used, both for initial detection of seroprevalence of BT from the four state-owned herds, and also for the monthly routine checks of the two sentinel herds.

Ag Capture ELISA test: After each detection of seroconversion in the cattle forming the sentinel herds, an Ag Capture ELISA test was performed to determine the virus presence in the blood samples of seropositive animals.

ECE Inoculation: The anticoagulated blood samples of sentinel herd cattle, which were found to have BT specific antibodies by previous serological surveillance, were inoculated in yolk sacs of nine-day-old embryonated chicken eggs (ECE). Pathological changes were then evaluated at $5^{\text {th }}$ days post inoculation.

Cell Culture Inoculation: Embryos having BT indicative pathological lesions were homogenized and subsequently inoculated onto Vero cell monolayer grown in 6-well plates. The cells inoculated were monitored by daily microscopic examinations for at least 7 days.

Virus Neutralization Assay and Detection of $S N_{50}$ Value: Cross neutralization tests against BT type 4, 9 and 16 were performed at different time periods on the serum samples of individuals with the highest antibody titers from the seroconversion determined of each sentinel herds. Determination of average neutralizing antibody titer $\left(\mathrm{SN}_{50}\right)$ was also performed on the seropositive animals' blood sera to detect the average antibody titers.

\section{Results}

Competitive ELISA test: From the 1440 initial blood sera samples taken from the state-owned herds, seroprevalence were found to be at $\% 12.3(40 / 324)$ in herd I, \%1.21 (6/495) in herd II, \%35.18 (146/415) in herd III, and \%0.48 (1/206) in herd IV by competitive ELISA test detecting specific antibody presence against $\mathrm{BT}$ virus.

Table 1. The amount of serum samples in herds.

Tablo 1. İşletmelerden genel tarama amaçlı toplanan serum miktarları

\begin{tabular}{cccc}
\hline Herd Nr. & $\begin{array}{c}\text { Sampled } \\
\text { animal nr. }\end{array}$ & $\begin{array}{c}\text { Seropositive } \\
\text { animal nr. }\end{array}$ & $\begin{array}{c}\% \\
\text { Seroprevalance }\end{array}$ \\
\hline I. & 324 & 40 & 12.3 \\
II. & 495 & 6 & 1.21 \\
III. & 415 & 146 & 35.18 \\
IV & 206 & 1 & 0.48 \\
\hline T O T A L & 1440 & 193 & 13.4 \\
\hline
\end{tabular}

From this data, animals from herd II in the northeast Anatolian region and herd III in the southeast Anatolian region were selected to constitute the sentinel herds. One hundres and fourteen seronegative cattle, aged between 6-18 months, from herd II, and 101 from herd III made up the sentinel herds. 
Table 2. Sampling periods of sentinel herds in govermental herds.

Tablo 2. İşletmelerdeki nöbetçi sürülerin örnekleme dönemleri

\begin{tabular}{|c|c|c|c|c|c|c|c|c|c|c|c|c|c|c|}
\hline & \multicolumn{14}{|c|}{ Sampling Period } \\
\hline & 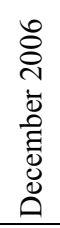 & 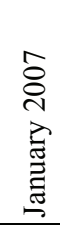 & 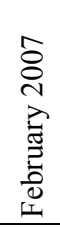 & 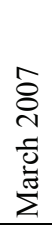 & 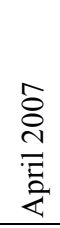 & 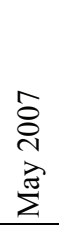 & 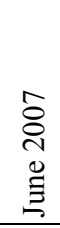 & 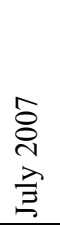 & 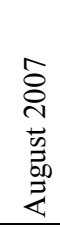 & 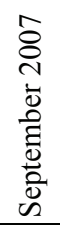 & 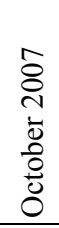 & 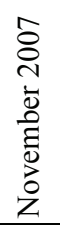 & 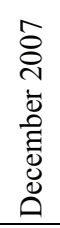 & 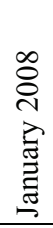 \\
\hline Herd II & $\mathrm{X}$ & & $\mathrm{X}$ & $\mathrm{X}$ & & $\mathrm{X}$ & $\mathrm{X}$ & & $\mathrm{X}$ & $\mathrm{X}$ & $\mathrm{X}$ & $\mathrm{X}$ & $\mathrm{X}$ & $\mathrm{X}$ \\
\hline Herd III & $\mathrm{X}$ & & $\mathrm{X}$ & $\mathrm{X}$ & $\mathrm{X}$ & & $\mathrm{X}$ & $\mathrm{X}$ & $\mathrm{X}$ & $\mathrm{X}$ & & $\mathrm{X}$ & $\mathrm{X}$ & $\mathrm{X}$ \\
\hline
\end{tabular}

Table 3. Spesific bluetongue antibody serotypes in blood serum of seroconversion detected sentinel cows of herd III.

Tablo 3. İşletme III nöbetçi sürüsünde serokonversiyon gösteren sığırların kan serumlarında tespit edilen spesifik mavidil antikor serotipleri.

\begin{tabular}{|c|c|c|c|c|}
\hline \multirow[b]{2}{*}{ Row Nr. } & \multirow[b]{2}{*}{ Ear Nr. } & \multicolumn{3}{|c|}{ Ab serotype of BT } \\
\hline & & BT-4 & BT-9 & BT-16 \\
\hline 1 & 636 & $\mathrm{X}$ & $\mathrm{X}$ & $\mathrm{X}$ \\
\hline 2 & 728 & $\mathrm{X}$ & $\mathrm{X}$ & $\mathrm{X}$ \\
\hline 3 & 660 & $\mathrm{X}$ & $\mathrm{X}$ & $\mathrm{X}$ \\
\hline 4 & 426 & $\mathrm{X}$ & $\mathrm{X}$ & $\mathrm{X}$ \\
\hline 5 & 375 & $\mathrm{X}$ & $\mathrm{X}$ & $\mathrm{X}$ \\
\hline 6 & 732 & $\mathrm{X}$ & $\mathrm{X}$ & $\mathrm{X}$ \\
\hline 7 & 313 & $\mathrm{X}$ & $\mathrm{X}$ & $\mathrm{X}$ \\
\hline 8 & 378 & $\mathrm{X}$ & $\mathrm{X}$ & $\mathrm{X}$ \\
\hline 9 & 319 & $\mathrm{X}$ & $\mathrm{X}$ & $\mathrm{X}$ \\
\hline 10 & 239 & & $\mathrm{X}$ & \\
\hline 11 & 489 & & $\mathrm{X}$ & $X$ \\
\hline 12 & 756 & $\mathrm{X}$ & $\mathrm{X}$ & $\mathrm{X}$ \\
\hline 13 & 719 & $\mathrm{X}$ & $\mathrm{X}$ & $\mathrm{X}$ \\
\hline 14 & 386 & $\mathrm{X}$ & $X$ & $\mathrm{X}$ \\
\hline 15 & 740 & $\mathrm{X}$ & $\mathrm{X}$ & $\mathrm{X}$ \\
\hline 16 & 710 & & $\mathrm{X}$ & $\mathrm{X}$ \\
\hline
\end{tabular}

All the cattle from the two sentinel herds, which were seronegative in November 2006, were sampled again 11 times over the next year, the sampling times are shown in table 2. Competitive ELISA test detecting specific antibody presence against BT virus was performed on blood sera in each sampling. None of the 114 individuals from herd II showed seroconversion during any sampling period. However, seroconversion was observed in 32 cattle from the herd III at various sampling dates (table 3 ).

Ag Capture ELISA test: BT antigen was not found in blood samples of seroconverted animals using antigen capture ELISA.

ECE inoculation: Although antigen was not detected by antigen capture ELISA test, anticoagulated blood samples of seroconverted cattle were inoculated in to yolk sacs of ECE. Pathological changes characterized growth retardation and generalized hemorrhages were observed in two of the embryos.

\begin{tabular}{ccccc}
\hline & \multicolumn{4}{c}{ Ab serotype of BT } \\
Row Nr. & Ear Nr. & BT-4 & BT-9 & BT-16 \\
\hline 17 & 325 & X & X & X \\
18 & 267 & X & X & X \\
19 & 370 & X & X & X \\
20 & 383 & X & X & X \\
21 & 576 & X & X & X \\
22 & 509 & X & X & X \\
23 & 647 & X & X & X \\
24 & 347 & X & X & X \\
25 & 673 & X & X & X \\
26 & 412 & X & X & X \\
27 & 270 & & $X$ & X \\
28 & 279 & X & X & X \\
29 & 260 & X & X & X \\
30 & 295 & X & X & X \\
31 & 494 & X & X & X \\
32 & 580 & X & X & X \\
\hline
\end{tabular}

Cell Culture inoculation: Bluetongue virus was not isolated from the Vero cells inoculated with the homogenates obtained from pathological embryos.

Virus Neutralization Assay and Detection of $S_{50}$ Value: The cross neutralization test performed against BT-4, BT-9, BT-16 on the blood sera showed seroconversion in 32 individuals, of which 28 had specific antibody against BT-4, BT-9 and BT-16, 2 had them against BT-9 and BT-16, and 1 had them against only BT-9 (table 3 ).

Results of the $\mathrm{SN}_{50}$ test performed against BT-4, BT-9 and BT-16 in different sampling periods on 16 of the 32 animals which had the highest titers are shown on table 4 . While antibody titers against BT-4 and BT-16 varied between undiluted samples to $1 / 80$, antibody titers against BT-9 were detected between $1 / 40$ and $1 / 1280$. Tables 3 and 4 indicate that, considering the low levels of cross neutralization, BT-9 was detected as the dominant circulating virus type in the area. 
Table 4. $\mathrm{SN}_{50}$ test results of BT-4, BT-9 and BT-16 at different times of seroconversion detected some cows.

Tablo 4. Serokonversiyon gösteren bazı sığırların kan serumlarının farklı dönemlerde, BT-4, BT-9 ve BT-16'ya karşı SN S0 $_{50}$ testi sonuçları.

\begin{tabular}{|c|c|c|c|c|c|c|c|c|c|c|c|c|c|}
\hline \multirow{2}{*}{$\begin{array}{c}\text { Row } \\
\text { Nr. }\end{array}$} & \multirow{2}{*}{$\begin{array}{l}\text { Ear } \\
\text { Nr. }\end{array}$} & \multicolumn{3}{|c|}{ April 2007} & \multicolumn{3}{|c|}{ July 2007} & \multicolumn{3}{|c|}{ September 2007} & \multicolumn{3}{|c|}{ December 2007} \\
\hline & & BT-4 & BT-9 & BT-16 & BT-4 & ВТ-9 & BT-16 & BT-4 & BТ-9 & BT-16 & BT-4 & ВТ-9 & BT-16 \\
\hline 1 & 636 & $1 / 20$ & $1 / 640$ & $1 / 10$ & & & & & & & & & \\
\hline 2 & 728 & $1 / 40$ & $1 / 160$ & $1 / 20$ & & & & & & & & & \\
\hline 3 & 660 & $1 / 80$ & $1 / 160$ & $1 / 40$ & & & & & & & & & \\
\hline 4 & 426 & UD* & $1 / 320$ & $1 / 40$ & & & & & & & & & \\
\hline 5 & 375 & $1 / 20$ & $1 / 80$ & $1 / 20$ & & & & & & & & & \\
\hline 6 & 313 & & & & UD & $1 / 320$ & UD & UD & $1 / 640$ & $1 / 10$ & & & \\
\hline 7 & 378 & & & & $1 / 20$ & $1 / 640$ & $1 / 20$ & & & & & & \\
\hline 8 & 319 & & & & UD & $1 / 40$ & $1 / 10$ & $1 / 20$ & $1 / 320$ & $1 / 40$ & & & \\
\hline 9 & 239 & & & & - & $1 / 160$ & - & & & & & & \\
\hline 10 & 489 & & & & & & & & & & - & $1 / 640$ & $1 / 20$ \\
\hline 11 & 756 & & & & & & & & & & $1 / 10$ & $1 / 640$ & $1 / 10$ \\
\hline 12 & 719 & & & & & & & & & & UD & $1 / 640$ & $1 / 20$ \\
\hline 13 & 386 & & & & & & & & & & $1 / 10$ & $1 / 320$ & UD \\
\hline 14 & 740 & & & & & & & & & & $1 / 10$ & $>1 / 1280$ & $1 / 80$ \\
\hline 15 & 710 & & & & & & & & & & - & $>1 / 1280$ & $1 / 40$ \\
\hline 16 & 325 & & & & & & & & & & $1 / 10$ & $>1 / 1280$ & $1 / 80$ \\
\hline
\end{tabular}

*UD: Undiluted

\section{Discussion}

BT, seen in many tropical and sub-tropical regions, is an infection of both domestic and some wild ruminants, transmitted by biting flies, characterized by congestion, edema and hemorrhage. It results in economic losses caused by abortions and congenital malformations. The infection was first detected in the USA in 1952, where it caused serious economic damage, and reportedly reached $\% 100$ morbidity rates in naive flocks in $1953(9,13)$. Infection was also reported in 1940 from Palestine, in 1956 from Spain and Portugal, in 1958 from Pakistan, and in 1977 from Australia, Greece and Israel. (6,13). Since 1998, a BT epizooty affecting Bulgaria, Greece, Italy, Portugal and the Aegean islands is ongoing (12). The infection has been recorded in Cyprus since 1924, where, during an epidemic in which morbidity reached \% 60-70, 400 sheep reportedly died in 1939 and 2,500 died in 1943 (17).

In Turkey, the presence of BT infection has been known since 1944, and it has been detected by several researchers $(2,8,11,18,20)$. Burgu et al (1), found the infection rate in cattle to be \%0-52.1 in the south, southeast and aegean regions. Recent isolation studies proved that various serotypes of the agent exist. Studies on the isolated virus in 1999 from the Trace identified it as BT virus type-9. Mellor and Wittmann (2002), reported that BT infection has been active since 1998 in south and west Anatolia and BT virus-type 16 was isolated during an outbreak in 2000. Since 1998, BT infection epizooties have been reported from Bulgaria, Greece, Italy, Portugal and the Aegean islands (12). In
Turkey, 4 different serotypes (types-2, 4, 9 and 16) have been identified from the 24 serotypes of BT virus $(2,12)$. Yildirım (2003) sampled 506 cattle from 8 cities of the northeast Anatolian region and found $243(\% 48.02)$ of them were positive using the virus neutralization test. Özgünlük (2003) also collected 890 blood samples from cattle in the southeast Anatolian region and found 468 (\%52.58) of them were seropositive for BT virus type 4. The detection of neutralizing antibodies against BT virus type 4 in both studies proves the need to implement a regional and serotype specific vaccination program for preventing the disease.

The northeast and southeast Anatolian regions were chosen for this study for several reasons: the high seroprevalence caused by both geographical and climate features; the probability of different serotypes entering the region from neighboring countries due to wind-borne long-distance transport of the virus via biting flies; and the current inadequacy of information about the serotype or serotypes causing local BT infection.

The southeast region has developed irrigated farming and this has caused a significant change to the ecological balance of the region. The most striking change is the survival rates and/or variety of the population of biting flies that are able to act as vectors of various pathogens. The same situation is also partially true for the northeast Anatolian region. The serious lack of awareness about economically significant viral infections such as BT is an issue with the neighboring countries of these regions in Turkey. Considering these needs, 2 governmental herds from northeast and 
southeast Anatolian regions were selected as target sentinel herds for the study.

Preparatory work was carried out to detect the herd prevalence by random sampling in the herd I and herd II in the northeast Anatolian region. BT seroprevalence was found to be $\% 12.3$ in the herd I and $\% 1.21$ in the herd II. It was decided to perform a monthly routine sampling from the sentinel herds derived from the herd II. In the southeast Anatolian region, random sampling revealed a rate of $\% 35.18$ seroprevalence in the herd III and $\% 0.48$ in the herd IV. The herd III was selected to form the sentinel herd as it had a large animal population and was also more stricken with BT virus infection.

The second step of the study was defining the sentinel herds (seronegative-susceptible) from the herd II in the northeast Anatolian region and the herd III in the southeast Anatolian region. One hundred and fourteen susceptible seronegative cattle aged between 6-18 months were selected from the herd II, and 101 from the herd III. A total of 11 samples were taken from the sentinel herds, beginning in December 2006. The sampling dates are shown in table 2.

None of the animals from the herd II showed seroconversion during the sampling period. That is, all the originally seronegative individuals completed the program seronegative. However, some individuals from the sentinel herd III showed seroconversion at various sampling dates. From February 2007, individuals were carrying BT antibody, and over the remaining sampling period, antibodies in blood sera varied across different individuals. To detect BT antibody in blood sera, competitive ELISA was used which can detect neutralizing antibodies against all 24 serotypes of the virus. Thus, all neutralizing antibodies against BT virus were detected by the competitive ELISA test in use. The detection of BT antibodies in blood samples from previously seronegative-susceptible individuals by February may indicate that climatic changes caused by global warming have affected the life cycles of the flies (especially in tropical and subtropical areas).

It also suggests that cattle acting as a reservoir for this infection and the flies continuing their life cycles represent serious long-term threats for sheep, which are the main host. Each seroconversion showing an individuals' EDTA blood sample was subjected to antigen capture ELISA test. Antigen could not be detected in any of the performed antigen capture ELISA tests. This inability to detect any antigens in the blood samples of individuals showing seroconversion is associated with both the probability of the development of specific antibodies during this period and also the sensitivity of the test.

Blood samples from the animals showing seroconversion were inoculated to ECE. Growth failure and general hemorrhages were seen on two of the embryones inoculated with the EDTA blood samples. Nevertheless, the virus could not be isolated from the Vero cell cultures after blind passage with the extracts from the embryones. Alterations in BT antibody presence blood samples from 32 animals were detected in 11 samplings during one year. The 32 cattle showing seroconversion were ordered from the one carrying the BT antibody for the longest period to the one for the shortest period. From the 32 individuals, 28 were found to have neutralizing antibodies against BT serotypes 4, 9 and 16, 3 against 9 and 16, and 1 against only 9 (table 3 ). $\mathrm{SN}_{50}$ test was performed for BT-4, BT-9 and BT-16 to determine the antibody titers of those 16 cattle which showed seroconversion and had the highest titers during the sampling periods. The results (table 4) showed that the antibody titers against BT-9 were much higher, and that these antibodies had low cross reaction with BT-4 and BT-16. This provides important evidence that BT-9 is the dominant circulating BT serotype in area of this study.

Currently in Turkey, vaccination is only carried out against BT serotype-4 to reduce the cost. However, the results of this study suggest that the specific vaccination of animals for the regionally dominant virus, and the production and usage of vaccines with two or even three serotypes in these areas would seem to be a more effective way to prevent the disease. Following this study to define the dominant BT virus serotype in two regions in Turkey, the relevant authorities were advised to perform an effective and protective vaccination to prevent the disease by producing type-specific vaccines.

\section{References}

1. Burgu İ, Urman HK, Akça Y, Yonguç A, Mellor PS, Hambling C (1992): Serologic survey and vector surveillance for bluetongue in southern Turkey. In: Bluetongue, African Horse Sickness and Related Orbivirusus. Ed.: T. E. Walton, B. I. Osburn, Crs. Press Inc, Boca Raton Fla, 168-174.

2. Ertürk A (1994): Çeşitli serumlarda (koyun, keçi, sığır) mavidil antikorlarının agar-jel presipitasyon testi ile araştırılması. Etlik Vet. Mikrobiol. Derg., 7(5), 1-19.

3. Gibbs EP, Greiner EC (1994): The epidemiology of bluetongue. Comparative Immunology. Microbiology and Infectious Disease, 17, 207-220.

4. Goldsmit L, Barzilai E, Tarmor A (1975): The comparative sensitivity of sheep and chicken embrios to bluetongue virus and observations on viremia in experimentally infected sheep. Aust Vet J, 51(4), 190-196.

5. Gorman BM (1990): The bluetongue viruses. Curr Top Microbiol Immunol, 162, 1-19.

6. Hassan A (1992): Status of Bluetongue in the Middle East and Asia. In: bluetongue, African Horse sickness and related orbiviruses. Ed.: T.E. Walton B I, Osburn Crs, Press. Inc., Fla., 38-41. 
7. Hawkes RA (1996): The global distrubution of bluetongue. Proceeding of the first Southeast Asia and Pasific Regional Bluetongue Symposium. Kunming, August 22-24, 6-14.

8. Hazıroğlu R (1987): Buzağılarda hydranencephalie olgularında patolojik-anatomik bulgular. Doktora Tezi, A Ü Sağl Bilm Enst, Ankara.

9. Hourrigan JL, Klingsporn AJ (1975): Epizootiology of bluetongue: The situation in The United State of America. Aust Vet J, 51(4), 203-208.

10. Luedke AJ, Jochim MM, Jones RH (1977): Bluetongue in cattle: effects of clucoides variipennis- transmitted bluetongue virus on pregnant heifers and their calves. Am J Vet Res, 38(11), 1687-1695.

11. Mellor PS, Jennings DM, Hambling C, Burgu I, Urman HK, Akça Y, Hazıroğlu R, Alkan F, Yonguç AD, Özkul A, Eren H (1995): Control of akabane disease and surveillance of bluetongue and ephemeral fever. United Nations Development Programme, Food and Agriculture Organization of the United Nations, Rome.

12. Mellor PS, Wittmann EJ (2002): Bluetongue virus in the mediterranean basin 1988-2001. Vet J, 164(1), 20-37.

13. Mertens PPC (1999): Orbiviruses and Coltiviruses. In: Encyclopedia of Virology. Ed: Granoff A, Webster R G, Vol 2, harcourt sience and Technology Company, Academic Press, San Diego Calif, USA, 1043-1061.

14. Murphy FA, Gibbs JEP, Horzineck CM, Studdent MJ (1999): Veterinary Virology, $3^{\text {th }}$ Edition, Raven Press Ltd. New York, USA.
15. Özgünlük İ (2003): Güneydoğu Anadolu bölgesi (GAP) kapsamindaki bölgede siğırlarda Mavidil, Akabane ve İberaki enfeksiyonlarının seroepidemiyolojisi. AÜ Sağl Bil Enstitüsü, Doktora tezi.

16. Roy P (2002): Orbivirus. Ed: C.D. Tidona, G.Darai. The Springer Index of viruses. Springer-Verlag. Berlin, Germany, 957-963.

17. Sellers RF (1975): Bluetongue in Cyprus. Aust Vet J, 51(4), 198-203.

18. Urman HK, Milli Ü, Mert N, Berkin, S., Kahraman, M. M., Yüce, H., Avvuran, H. (1979): Türkiye'de buzağılarda konjenital epizootik arthrogriphosis ve dranencephalie olaylart. AÜ Vet Fak Derg, 26: 287-292.

19. Yıldırım Y (2003): Kuzeydoğu Anadolu bölgesindeki siğırlarda Mavidil, IBR, PI-3, EBL ve BVD enfeksiyonlarının seroprevalansı. AÜ Sağl Bil Enstitüsü, Doktora tezi.

20. Yonguç AD, Taylor WP, Csonton L, Worrall E (1982): Bluetongue in western Turkey. Veterinery Record, 111, 144-146.

Geliş tarihi: 10.02.2012 / Kabul tarihi: 03.05.2012

Address for correspondence :

Taner Karaoğlu, DVM, PhD.

Department of Virology, Faculty of Veterinary Medicine, Ankara University, Ankara,Turkey.

e-mail:karaoglu@ankara.edu.tr 